\title{
Inhibition of Angiotensin - Converting Enzyme by a Synthetic Peptide Fragment of Glyceraldehyde-3-phosphate Dehydrogenase
}

\author{
Ewa Seweryn ${ }^{\mathrm{a}, *}$, Artur Pędyczak ${ }^{\mathrm{b}}$ and Teresa Banaśa \\ a Wrocław Medical University, Department of Medical Biochemistry, Chałubińskiego 10, \\ 50-368 Wrocław. Poland. Fax: (+48) 0713285415. E-mail: ewo.seweryn@yahoo.com \\ b University of Wrocław, Department of Chemistry, Wrocław, Poland \\ * Author for correspondence and reprint requests \\ Z. Naturforsch. 55c, 657-660 (2000); received January 10/April 11, 2000 \\ Glyceraldehyde-3-phosphate Dehydrogenase, Angiotensin-Converting Enzyme Inhibitor, \\ Synthetic Peptide \\ A novel inhibitor of angiotensin - converting enzyme (ACE) identical to a sequence part \\ of human muscle glyceraldehyde-3-phosphate dehydrogenase (GAPDH) was chemically syn- \\ thesized. Amino acid sequence was as follows Pro - Glu - Asn - Ile - Lys - Trp - Gly - \\ Asp. This peptide inhibited rabbit lung ACE with a $\mathrm{K}_{\mathrm{i}}$ value of $1.6 \mu \mathrm{m}$. The inhibitor of ACE \\ acts in a non-competitive manner. The amino acid sequence of the new inhibitor was com- \\ pared of GAPDH from other sources.
}

\section{Introduction}

The renin - angiotensin system is important in the regulation of blood pressure and angiotensin converting enzyme (ACE; peptidyldipeptide hydrolase, EC 3.4.15.1). Inhibitors have been of great value for their hypotensive effect through this system. Competitive inhibitors of ACE were first obtained from venom of snakes such as Bothrops jararaca (Cheung et al.,1980) and Agkistrodon halys blomhoffi (Kato and Suzuki, 1971). These inhibitors have many proline residues. Another inhibitor of ACE has been isolated from an acid extract of tuna (Neothunnus macropterus) muscle (Kohama et al., 1989). This peptide was found to be a noncompetitive inhibitor different from many natural peptide inhibitors (Kohama et al., 1994). The amino acid sequence of tuna ACE inhibitor was similar as though not identical, to segments within the vertebrate GAPDH family (Kohama et al., 1989).

Thus the attention of many laboratories were focused on a family of ACE inhibitory peptides excised from vertebrate and prokaryote GAPDH (glyceraldehyde-3-phosphate dehydrogenase, EC 1.2.1.12) by acid-limited proteolysis (Kohama et al., 1989).

In this paper, the inhibitory effect of a synthetic peptide, identical to the peptide 79-86 of the human muscle GAPDH was studied. The complete amino acid sequence of this enzyme was estab- lished earlier in our laboratory (Nowak et al., 1989). The structure of the human peptide is similar to the active inhibitors of ACE from rat, chicken and tuna muscle glyceraldehyde-3-phosphate dehydrogenase.

\section{Materials and Methods}

Materials - Peptidyldipeptide hydrolase (ACE; EC 3.4.15.1) from rabbit lung, hippuryl-L-histydylL-leucine (Hip-His-Leu), L-histydyl-L-leucine (His-Leu) were purchased from Sigma Chemical (Mo., USA).

All others reagents and solvents were obtained from Serva, Germany.

Peptide synthesis - The peptide: Pro-Glu-AsnIle-Lys-Trp-Gly-Asp was synthesized by conventional solid phase method using an automated peptide synthesizer (Applied Biosystems Inc., model - $430 \mathrm{~A}$ ), followed by treatment with hydrogen fluoride to cut off the support resins and to remove all of the protecting groups (Merrifield, 1985). The synthesized peptide was purfied by reverse phase high performance liquid chromatography on Develosil ODS-7 column $(0.46 \times 25 \mathrm{~cm})$ eluted with a $5-30 \%$ acetonitrile in $0.05 \% \mathrm{HCl}$ (linear gradient). After that the peptide was run on a Asahipak GS-220 column $(0.76 \times 25 \mathrm{~cm})$ eluted with $50 \mathrm{~mm}$ sodium phosphate buffer, $\mathrm{pH}$ 7.0. The results of amino acid analyses and sequence analyses agreed well with expected values. 
ACE activity assay - The activity of ACE was assayed by fluorometrically (Cheung et al., 1973) of the rate of formation of histidylleucine from Hip-His-Leu. Incubations were carried out at $37^{\circ} \mathrm{C}$ in final volume of $0.25 \mathrm{ml}$, which contained $100 \mathrm{~mm}$ potassium phosphate buffer ( $\mathrm{pH} \mathrm{8.3)}$, $300 \mathrm{~mm} \mathrm{NaCl}$, enzyme (activity $3.4 \mathrm{U} / \mathrm{mg}$ ) and $2.5 \mathrm{~mm}$ Hip-His-Leu. The enzymatic reactions were terminated by addition of $1.45 \mathrm{ml}$ of $0.3 \mathrm{M}$ $\mathrm{NaOH}$ and $100 \mu \mathrm{l} 0.2 \%$ o-phthaldialdehyde was then added, followed after $10 \mathrm{~min}$. by $0.2 \mathrm{ml}$ of $3 \mathrm{M}$ $\mathrm{HCl}$. The fluorescence was measured with PerkinElmer MPF 3L spectrofluorimeter $\left(\lambda_{\mathrm{ex}}=360 \mathrm{~nm}\right.$, $\lambda_{\mathrm{fl}}=500 \mathrm{~nm}$ ).

ACE activity was assayed in the presence or absence of inhibitor and compared to controls containing no inhibitor. In other experiments our inhibitor was preincubated with various concentrations of $\mathrm{ZnCl}_{2}$ for $5 \mathrm{~min}$. at $37{ }^{\circ} \mathrm{C}$ before the reaction was started.

\section{Results}

The amino acid sequence of the peptide inhibitor of ACE, obtained synthetically, was as follows: Pro-Glu-Asn-Ile-Lys-Trp-Gly-Asp. This sequence corresponds to the peptide 79-86 from human skeleton muscle GAPDH.

Figure 1 shows the Lineweaver-Burk plot of inhibition of rabbit lung ACE catalyzed hydrolysis of Hip-His-Leu by synthetic peptide. Activity of ACE in control sample (non-inhibited) was 3.4 $\mu \mathrm{mol} \cdot \mathrm{mg}$ protein ${ }^{-1} \cdot \min ^{-1}$. This peptide inhibited the enzyme non-competitively. The $\mathrm{K}_{\mathrm{i}}$ value was calculated by Dixon method was $1.6 \mu \mathrm{m}$. $\mathrm{I}_{50}$ value (concentration of inhibitor producing a $50 \%$ inhibition of ACE) was $3.7 \mu \mathrm{m}$. With great excess of this inhibitor only about $80 \%$ inhibition of ACE was obtained.

It is well known, that EDTA inhibits the activity of ACE by chelating the enzyme bound $\mathrm{Zn}^{+2}$. This inhibition may be reversed by addition of $\mathrm{Zn}^{+2}-$ containing solutions to the reaction mixture. Results are shown in Table I. The addition of $\mathrm{Zn}^{+2}$ ions reversed completely the inhibition by EDTA, but had only minor influence on the inhibition by the synthetic peptide, diminishing it by 5 and $10 \%$.

When this synthetic peptide (inhibitor) was preincubated without $\mathrm{ZnCl}_{2}$, its ACE inhibitory activity was about $50 \%$. When 10 or $20 \mu \mathrm{M} \mathrm{ZnCl}_{2}$ was

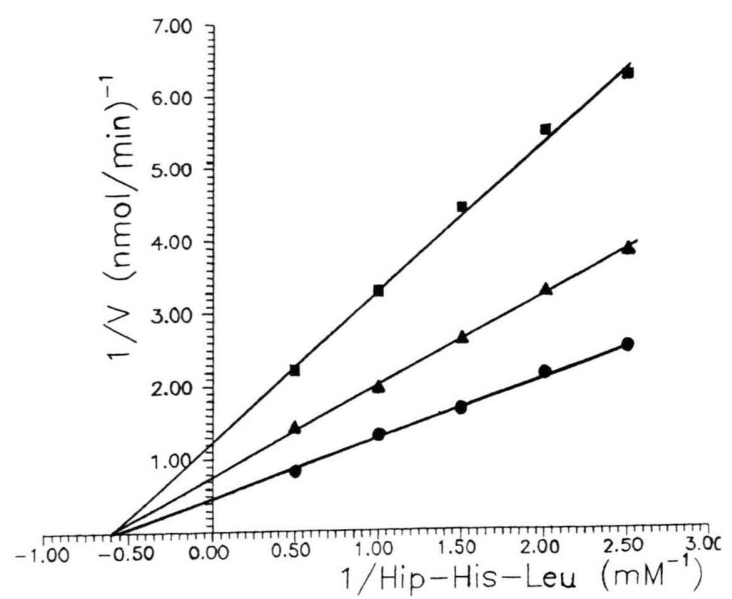

Fig. 1. Lineweaver-Burk plots of inhibition of rabbit lung ACE by synthetic peptide corresponding to sequence of GAPDH. ACE concentrations was $6 \mathrm{mU}$ for assay, 1 unit of ACE activity is defined as the amount catalyzing the formation of $1 \mu \mathrm{mol}$ of hippuric acid from Hip-HisLeu in $1 \mathrm{~min}$. at $37^{\circ} \mathrm{C}$. Inhibitor concentration: -0 $\mu \mathrm{M}, \boldsymbol{\Delta}-3 \mu \mathrm{M}, \boldsymbol{\mathbf { a }}-6 \mu \mathrm{M}$.

Table I. Effect of $\mathrm{ZnCl}_{2}$ on inhibition of $\mathrm{ACE}$ by synthetic peptide corresponding to sequence GAPDH from human muscle and by EDTA. Synthetic peptide $(3 \mu \mathrm{M})$ or EDTA $(3 \mu \mathrm{M})$ was preincubated with the indicated concentrations of $\mathrm{ZnCl}_{2}$ at $37^{\circ} \mathrm{C}$ for $5 \mathrm{~min}$ before the enzyme reaction was initiated.

\begin{tabular}{lcc}
\hline Sample & $\mathrm{ZnCl}_{2}(\mu \mathrm{M})$ & ACE inhibition (\%) \\
\hline Synthetic peptide $(12 \mu \mathrm{M})$ & 0 & 80 \\
\hline \multirow{2}{*}{ Synthetic peptide $(3 \mu \mathrm{M})$} & 6 & 50 \\
& 10 & 45 \\
& 20 & 41 \\
\hline & 0 & 65 \\
EDTA $(3 \mu \mathrm{M})$ & 5 & 6 \\
& 15 & 0 \\
\hline
\end{tabular}

With $12 \mu \mathrm{M}$ synthetic peptide an $80 \%$ inhibition could be obtained al maximum.

added respective inhibitory activities were 45$41 \%$. The influence of EDTA on ACE - which was added after preincubation with $\mathrm{ZnCl}_{2}$ is shown in Table I. These data indicate that this synthetic peptide that corresponds to sequence 7986 from human skeleton muscle GAPDH does interact with $\mathrm{Zn}^{+2}$ - ions (Krotkiewska and Banaś, 1992). 


\section{Discussion}

Angiotensin - converting enzyme catalyses the cleavage of the C-terminal dipeptide L-His-L-Leu of the decapeptide angiotensin I, generating the biologically highly active vasopressor angiotensin II.

Since ACE is a dipeptidyl carboxypeptidase, the C-terminal tripeptide fragment of the inhibitory peptides from snake venom is predominant in its competitive binding to the enzyme. The terminal aromatic amino acid is favorable for effective binding of peptide inhibitors to the active site of the enzyme (Kohama et al., 1991). The synthetic peptide shows a non-competitive mode of inhibition. All of the octapeptides in Table II have a dicarboxylic acid Asp as terminal and Gly as penultimate, and the amino acid sequence is different from those of the venom peptide family (Cheung and Cushman, 1973; Cheung et al., 1980). These facts may support a non-competitive inhibition of ACE by these inhibitors. Differences of amino acid sequence evident at the position 80 of GAPDH - derived peptides seem not to influence their inhibitory activity.

ACE contains zinc ions which plays an important role in the active site (Wei et al., 1991). EDTA shows a powerful inhibitory activity by chelating
Table II. Sequence homology of glyceraldehyde-3-phosphate dehydrogenase (GAPDH) peptides.

\begin{tabular}{|c|c|c|c|c|c|c|c|c|c|}
\hline Position & 79 & 80 & 81 & 82 & 83 & 84 & 85 & 86 & Source \\
\hline \multirow[t]{5}{*}{$\mathrm{AA}$} & $\mathrm{P}$ & $E$ & $\mathrm{~N}$ & I & $\mathrm{K}$ & W & G & D & $\begin{array}{c}\text { Human (Nowak } \\
\text { et al., 1981) }\end{array}$ \\
\hline & $\mathrm{P}$ & A & $\mathrm{N}$ & I & $\mathrm{K}$ & W & G & D & $\begin{array}{l}\text { Porcine (Harris and } \\
\text { Perham, 1968) }\end{array}$ \\
\hline & $\mathrm{P}$ & A & $\mathrm{N}$ & I & $\mathrm{K}$ & W & G & D & $\begin{array}{c}\text { Rat (Tso et al., } \\
\text { 1985) }\end{array}$ \\
\hline & $\mathrm{P}$ & $\mathrm{S}$ & $\mathrm{N}$ & $\mathrm{I}$ & $\mathrm{K}$ & W & $\mathrm{A}$ & $\mathrm{D}$ & $\begin{array}{c}\text { Chicken (Domdey } \\
\text { et al., 1983) }\end{array}$ \\
\hline & $\mathrm{P}$ & $\mathrm{T}$ & $\mathrm{N}$ & I & $\mathrm{K}$ & W & G & D & $\begin{array}{c}\text { Tuna (Kohama } \\
\text { et al., 1994) }\end{array}$ \\
\hline
\end{tabular}

the ACE active site for zinc. Its main inhibitory mechanism was shown to be a chelating effect, because saturation with exogenous zinc abolishes inhibition by EDTA. However, our synthetic peptide did not show any zinc chelating effect. It seems that its inhibitory mechanism is non-competitive in our assay condition with Hip-His-Leu.

Although our peptide is only a moderately strong inhibitor of ACE, compared to known ACE inhibitors, it is noteworthy that this peptide from human muscle GAPDH inhibits rabbit lung ACE in a non-competitive manner. In pathological states resulting in protein degradation GAPDH could be proteolized. It could be the reason of additional decrease of blood pressure. 
Cheung H. S. and Cushman D. W. (1973), Inhibition of homogeneous angiotensin - converting enzyme of rabbit lung by synthetic venom peptides of Bothrops jararaca. Biochim. Biophys Acta 293, 451-463.

Cheung H. S., Wang F. L., Ondetti M. A., Sabo E. F. and Cushman D. W. (1980), Binding of peptide substrates and inhibitors of angiotensin - converting enzyme. J. Biol. Chem. 255, 401-407.

Domdey H., Wiebauer K., Klapthar H. and Arnold H. (1983), Sequence analysis of the cloned mRNA coding for glyceraldehyde-3-phosphate dehydrogenase from chicken heart muscle. Eur. J. Biochem. 131, $129-135$.

Harris J., and Perham R. N. (1968), Glyceraldehyde-3phosphate dehydrogenase from pig muscle. Nature 219, 1025-1028.

Kato H. and Suzuki T. (1971), Bradykinin-potentiating peptides from the venom of Agkistrodon halys blomhoffii. Isolation of five bradykinin potentiators and the amino acid sequences of two of them, potentiator B and C. Biochemistry 10, 972-980.

Kohama Y., Kuroda T., Iida K., Ithon S. and Mimura T. (1994), Inhibitory effect of tuna peptide on endothelin production in cultured endothelial cells. Biol. Pharm. Bull. 17, 886-888.

Kohama Y., Oka H., Kayamori Y., Tsujikawa K., Mimura T., Nagase Y. and Satake M. (1991), Potent synthetic analogues of angiotensin - converting enzyme inhibitor derived from tuna muscle. Agric. Biol. Chem. 55, 2169-2170.
Kohama Y., Oka H., Matsumoto S., Nakagawa T., MiyamotoT., Mimura T., Nagase Y., Satake M., Takane T. and Fujita T. (1989), Biological properties of angiotensin - converting enzyme inhibitor derived from tuna muscle. J. Pharmacobiodyn. 12, 566-671.

Kohama Y., Oka H., Yamamoto K., Teramoto T., Okabe M., Mimura T., Nagase Y. and Satake M. (1989), Induction of angiotensin - converting enzyme inhibitor by acid-limited proteolysis of glyceraldehyde-3-phosphate dehydrogenase. Biochem. Biophys. Res. Commun. 161, 456-460.

Krotkiewska B. and Banaś T. (1992), Interaction of $\mathrm{Zn}^{+2}$ and $\mathrm{Cu}^{+2}$ ions with glyceraldehyde-3-phosphate dehydrogenase from bovine heart and rabbit muscle. Int. J. Biochem. 24, 1501-1505.

Merrifield R. B. (1985), Solid-phase synthesis. Chemica Scripta 25, 121-131.

Nowak K., Wolny M. and Banaś T. (1981), The complete amino acid sequence of human muscle glyceraldehyde-3-phosphate dehydrogenase. FEBS. Lett. 134, $143-146$.

Wei L., Alhenc-Gelas F., Corvol P. and Clauser E. (1991), The two homologous domains of human angiotensin I - converting enzyme are both catalytically active. J. Biol. Chem. 266, 9002-9008.

Tso J. Y., Sun X. H., Kao T. N., Reece K. S. and Wu R. (1985), Isolation and characterization of rat and human glyceraldehyde-3-phosphate dehydrogenase cDNAs: genomic complexity and molecular evolution of the gene. Nucleic Acid Res. 13, 2485-2501. 